\title{
The Church, the Pulpit, and the Poor. the Role of Preaching in Poor Relief Efforts in the Thinking of Samuel Mccomb (1864-1938)
}

\author{
Simuț Ciprian, PhD \\ Emanuel University of Oradea, Romania \\ ciprian.simut@emanuel.ro
}

\begin{abstract}
The problem of the poor has been a constant in the life of nations. There have always been poor people to whom society, governments, and the Church have been looking in various ways across the ages. One important aspect is the way the Church has behaved in relation to the poor, because it is the institution that preaches a certain kind of moral code, and a certain kind of human value. This paper focuses on the role of preaching and the role of the Church in poor relief efforts, as presented in the writings of Samuel McComb (1864-1938). The main argument in the thought of McComb is that the Church will always need to be involved in poor relief efforts, but not simply by helping the poor with material needs, but also by offering spiritual guidance. These efforts should be coupled with the preparing of the believers to be directly involved in poor relief, based on a moral code, which is presented and explained from the pulpit.
\end{abstract}

Keywords: church, pulpit, preaching, poor, morals

\section{Introduction}

There is an important social factor in modern society that has retained its appeal for a great number people, namely the Church. A quick look at any church history book and one will certainly notice that the Church has played an important part in society, both in the realm of worldly affairs, as well as in the affairs of the soul. It is a fact that not all the actions of the Church were righteous, and abuses were quite frequent. However, it is doubtless that it had, and it still has, a genuine care for the poor, the afflicted, the abused, the orphan, the widow, and anyone who has a need. The following paper will analyze the arguments presented by Samuel McComb (1864-1938) regarding the importance of preaching for society, as well as the importance of preaching and the Church in poor relief efforts. The paper will focus mainly on the books written by McComb, but it will not looks at any statistical data, because the argument is based on his religious and pragmatic principles. The thesis of this paper is that preaching and the Church can have a positive impact in society, not by adapting to every aspect of social change, but by presenting a mature and well developed system of moral values. In spite of the fact that McComb was part of the Emanuel Movement, this paper will not analize any of the aspects related to the movement, mainly because the part of McComb's argument that is analyzed, has no direct link to the movement.

Samuel McComb begins the tenth chapter of his book, which bears the title Religion in Modern Society, with a straightforward question, which leaves no room for interpretations, namely what is the role of religion in modern society? The book in which this question is raised was published in 1910, more than a century ago. In the meantime the world has seen two world wars, countless regional wars, on various continents, the rise terrorism and the massive migration of population into Europe. Such events force thinkers to evaluate the role of society, its elements and they it is organized, in order to preserve or further the development of society.

\section{The Need for Religion in the Modern World}

As soon as he asks the question, McComb answers by showing how some of his contemporaries saw the relevance of religion for their time. The first category believes that religion is obsolete, there is no more rational or emotional use for it. However, it can still be tolerated as long as it acts as a police force in subduing the humbler classes. This idea presents 
some in favor of splitting society into classes, rather than pursuing the benefit and the elevation of one's neighbor. Such an idea can be detrimental to the entire idea of human progress. Dividing people into classes is not progress, but rather a quite shameful regress to darker times, when one was forced to live in a set environment and with a set value, due to one's birth. McComb connects this idea with that of a rather sexist remark, namely that religion can be tolerated if it is an 'aesthetic outfit of the feminine mind'. Such a remark reduces the role and value of a woman to a creature of whimsical emotions, rather devoid of any high rational capabilities. Downplaying the role of women with regards to religion and society is an obvious proof of devaluing women's value as human beings. This argument does not have to be connected to the feminist movement, or the equal rights movement, but to a clear and obvious fact of history: women have played as crucial roles in history as man have (McComb, 1910, p. 281).

After presenting this first category of people, McComb concludes that with such people there is no argument, because they define others as lesser beings. However, McComb believes that most people still consider religion as a reality. These people find it quite difficult to reconcile the role of religion with the realm of experience. For these men the question regarding the contribution of religion to modern life is particularly important, because it can set the difference between high or low human value. McComb begins his argument from the Church, which he claims is the 'institution which claims to represent the Christian religion, to incarnate the spirit of its Founder, and to realise His ideals' (McComb, 1910, p. 282). The problem is that the Church did and does not connect the idea to the deed. As McComb underlines, it appears the Church missed on incarnating these ideals. He looks at the life and work of Jesus Christ and his achievement, and the achievements of the Church. The difference is overwhelming. He also appeals to an earlier essay in which he depicts Christ as addressing his messages in two realms of human experience: normal and the abnormal, or the healthy and ordered state, or the disordered, unhealthy state. His question is whether the Church is able to live out both realities (McComb, 1910, p. 282).

The connection between principle and reality is represented by Jesus Christ himself. In order to make his point, McComb has to present the fundamentals of Christian life and practice. In this case, such a fundamental principle is the relationship between a spiritual office and the representative of that office. According McComb Christ had a prophetic ministry, which was passed from him to man by the office of the preacher. The preachers must fulfill a number of duties, that were fulfilled by Christ, otherwise, the connection is lost. McComb believes that the preacher should promote virtue by calling people to live it out. The pulpit therefore acts as a guide to morals and the active involvement in sustaining and promoting virtue. Preaching is one thing, but preaching with a specific purpose of fulfilling in one's life a set of principles is quite another. If the church, as an institution, and the preacher do not stand out in the crowd as a guide to virtue, the source of a specific kind of morals will be either lost, or presented by other institutions, which will, most likely, dilute it. The church stands out in society as a specific institution, which promotes a specific kind of ethos, through a specific kind of offices. These all orbit around the preacher's office (McComb, 1910, p. 282).

\section{The Hands-on Preacher}

Living out the Christian faith is no easy task. However, McComb argues that a preacher should resort only to preach. There is much more at stake for his office than talk from the pulpit on various themes. According to McComb the preacher needs to 'solve doubts and perplexities' (McComb, 1910, p. 283). The preacher's office has an intrinsic element of constant human interaction. Life is complicated and difficult. There are various challenges faced by church members on a daily basis. Problems vary from the simplest to the most complex. The job or better yet, the calling of the preacher is to know first of all his working material, the Bible, and then to adapt the timeless truths to the social, religious, political and economic context of the people he pastors. The church members face problems constantly, which they try to solve on their own. Some succeed, others do not. Regardless of the issues McComb argues that the preacher's task is to stay with his people and guide them. Doubts and perplexities, as McComb calls them, are no easy task, but the believers know that the preacher should be there for them to explain how to solve matters of the spirit and their application to every-day life. The preacher is, therefore, not a simple orator, but an actively involved person, who deals in morals (McComb, 1910, p. 283).

Another aspect of the preacher's activity is revealing 'new vistas of truth' (McComb, 1910, p. 283). In modern society there is no shortage of problems. People do not or cannot escape meeting other people and live in society, in connection to the other. This is in itself a problem, because it is the very source of inter-human friction. Therefore, the problems are quite big. Relational issues are present in one's private life, family life, social life, at work and in relation to the private and state institutions. Help can come from many, but the preacher stands out as the person who could do most good, because he 
deals in moral good and in applying such teachings to every day problems. The church and the ministers can become a decision making force in the relationships of believers and the rest of the world. The new vistas of truth are the teachings extracted from Scripture, understood in their proper context, and applied to new or modern or contemporary situations. In a most optimal scenario, the preacher is a highly educated person, who is able to see the way past teachings apply to contemporary and personal problems. However, this is not the case all the time. Higher education can be replaced with common sense and meekness. These two characteristics stop the preacher or the minister to express opinions in matters that he does not understand. The teachings of the Bible, the fundamental writings for the Christian minister, are, therefore the starting point for any debate, but its teachings must be adapted to the problem at hand. In some way, regardless of the problem presented, a dedicated minister will not abuse the Scripture, but will inevitably find some text within it, that he would use at least to better explain his own take on the problems.

McComb goes back to history in order to present his argument. He sees sermons as tools to awaken the conscience, to point out the abuses of power at all levels, to start and sustain revivals that changed the faces of nations, and guided people into the work of self-regeneration. In his mind there is no stopping what a well built sermon can do. A powerful message delivered from the pulpits or, where not possible, simply from the mouth of a well-prepared preacher changed cowards into heroes, moved people against evil, cleared the issues people struggled with, and even attempted to bring people out of the miseries of their time (McComb, 1910, p. 283). In short, McComb sees the element of the sermon as a paradigm shifter.

Having the history of Christianity and the history of preaching at hand, McComb rightly asks whether the power of preaching has past. One of the culprits was agnosticism. However, he sees this threat as passing. Its paralyzing power vanished, and the result was a revival of interest for the religious mysteries. However, McComb is quite realist, but with a touch of drama, and acknowledges that people will look not to the pulpit for solving their problems, but to the 'professor's lecture, the review article, the newer drama, the formal treatise' (McComb, 1910, p. 284). Due to the form and content of these elements, he argues that preaching or the sermon has lost its appeal. There was a power shift in his age, but not from agnosticism to faith, but from preaching to agnosticism to lay erudition. As McComb scans his historical context, he argues that, in spite of the appeal of academic thinking, but devoid of the spiritual, there is a resurgence of 'religious eloquence', because event if the 'Word of God is not bound' (McComb, 1910, p. 284). The weakest element in this context is not God or the Bible, but the preacher. If there is anything going wrong with religion, it is because man, more precisely: the preacher has done something wrong. McComb stresses the importance of preaching because it can make a difference for the real problems of man. Preaching is not only about God, but about God, man, and how the two interact. Therefore the sermons bring a palpable supernatural element into the every-day life of believers (McComb, 1910, p. 285).

The force of the preacher's sermon and the power of his influence are limited by a couple of elements. First, the preacher should make proper use of 'sound and thorough religious thinking, by the note of intellectual conviction' (McComb, 1910, p. 285). McComb blames the preachers of his time because they lack this element. The general sensation is that the preachers have never understood what intellectual depth their theology has. McComb presents this ideas as 'ethical and intellectual grandeur of Christianity' and 'its boundless wealth of truth which, touching man at every point, lifts him out of time into eternity and satisfies the craving of the intellect for unity largeness, and power' (McComb, 1910, p. 285). His definition of what Christianity deals with in terms of content, is important to help contemporary congregations, regardless of denomination and historical background, to lean towards and embrace the academic training of at least a part of its congregants and ministers. The reason is that when entering the realm of academic training the chances of understanding the philosophies and morals that can be different from the backbone of Scriptural teachings. When the contact between opposites takes place, argumentation gives birth to new ideas, new trains of thought, new ideological ground to discover. The contact breeds new understandings for all that makes human value count or not. McComb goes back into the history of preaching and he gives the examples of various preachers from all history of Christianity, so he argues in favor of rational interactions in order to discover and apply moral discernments to issues of every-day life (McComb, 1910, pp. 285-286).

McComb does not argue in favor of keeping the truths of old, but to re-vitalize the teachings of the Gospel for the understanding of modern man. The historical context is different, and modern man might have to face different problems, but the core text of Christianity is the same, namely the Bible. The job of the preacher is to 're-study and re-vitalise the regnant ideas of the Gospel of Christ, who will steep them in the living realities of experience and make them once more the possession of heart and conscience' (McComb, 1910, p. 286). McComb does not retreat into mysticism or extreme 
rationalism. He mingles the spiritual and the rational into a coherent system of teachings, which can aid modern man in his daily problems.

\section{Christianity and Moral Values}

Christianity as a useful tool for modern man is the main aspect of McComb's endeavors. Modern man could, but should not renounce Christianity out of whim. Instead, modern man should scout and research his options and devotions, in order to get the best context for his life on earth. Christianity is a matter of both heart and conscience. The rational and the spiritual are not mutually exclusive. McComb is aware of the capacity of preachers to speak with no practical application of their teachings in real life problems. Instead of simple exhortations, McComb suggests that preachers must implement positive suggestions for their audiences. The preachers deal in religious ideas, which can left in the high spheres of a spiritual intangibility. However, such an approach to sermons is counterproductive. The hearers must be given the method of applying the ideas about the spiritual and the moral realms into their daily situations. McComb makes an important remark about the spheres of knowledge. He argues that the preachers should not ignore the scientific and the practical means through which truth can be delivered. Science and the practical are not against the spiritual, and McComb argues in favor of both realms to interact. There is not spiritual truth that cannot be applied to daily life, as well as there is no scientific fact that can go against the spiritual truth (McComb, 1910, p. 286).

McComb was part of the Emmanuel Movement, which started in a church, and worked on the principle of mind over body, but with a strong emphasis on medicine and good habits. The aim of the movement was to cure various functional nervous disorders, with the aid of proper psychological methods. Positive suggestions were part of the methods of treatment, but also an active involvement of the spiritual side. God is a most active part of the healing process, but He does not heal all in the same way. Furthermore, the promoters of the Emmanuel Movement had to face detractors who argued that they lacked faith since they did not allow God to heal without the use of medicine. The answer was always the same, namely that God heals all and every disease, but in a close collaboration with the sick, who needs to re-order one's moral principles. As part of the healing process, hypnotism was also used (Elwood, McComb, \& Coriat, 1908). The Religion and Mind book covers all the fundamental details for understanding what and how Emmanuel Movement worked and what it stood for. The rationale behind McComb's argument in his Christianity and the Modern Mind is closely connected to the movement. He does not resume his activity to healing the functional disorders or various other physical ailments, but he focuses on the larger social sphere.

The practical side of McComb's approach is for people to understand what bad habits are, and how they can and need to be changed with good ones. His remark that 'it is not enough to glorify the face of goodness' (McComb, 1910, p. 287) is the foundation on which he argues in favor of eradicating poverty. McComb argues in favor of teaching the methods by which men may make goodness their own. Goodness is not something that grows by itself. It is learned and exercised. McComb presents the purpose and the importance the modern pulpit should have in modern society, namely to "be rich in suggestiveness, in scientific aim; in hints that make for practice' (McComb, 1910, p. 287). His opinion marks the importance of the spiritual and the religious to communicate and cooperate with the scientific. The pulpit should not deny the truth of science, lest it becomes absurd and stands to loose ground and people. The pulpit thus becomes a promoter of mental health and a communicator of spiritual truth in relation to science and scientific development. The church and the preacher do not impede and do not go against science, but accept in full knowledge the importance of science for the religious man and the believer. Also, the pulpit should not stand idle towards implementing the teachings of Scripture, or the moral side of the teachings into the every-day life of men. The practical side aims towards the repair of the functional psychological disorders and the healthy relationship with one's neighbor.

\section{The Two Kinds of Poverty}

After explaining what the purpose of preaching is, McComb addresses three issues of great interest for the modern man: poverty, sickness, and crime. This paper focuses on the presentation of McComb's perspective on poverty. Christianity does not rely on a cluster of miscellaneous writings, without having a central figure, whom focuses them into a coherent set of values. For Christianity the person of Christ is fundamental. Without him the message of Scripture would be a simple set of moral and historical teachings. Because traditional or conservative Christians see Christ as the Son of God and the second Person of the Holy Trinity, the entire Bible is considered as having absolute value. Therefore, issues such as poverty 
are not seen only as an inter-human relational issue, but it is a relation that has a spiritual foundation, as well as a Person who is actively involved in it. McComb presents the life of Christ as one deeply involved in to the lives of others. However, he marks the fact that Christ was especially close to the poor, the sick, and the unfortunate. The purpose of his friendship with these people was to relieve them of their suffering (McComb, 1910, pp. 287-288).

Of significance is the reversal of value, the Judgment scene (Matthew 25:31-46), where Christ identifies with the sick, the poor, and the criminal. Of these he was certainly poor, but the imagery can be extended. He became sick with the sin of humanity and a criminal in the eyes of the multitudes who accused and condemned him. The image is complete in the final perspective of his life and ministry. By identifying with the destitute, McComb believes that the moral standard is set not by the relationship of one with him, but by the relationship of one to another, having the foundation in faithfulness in Christ. One might possess the power and patience to build a set of actions that could alleviate poverty, and even propel one towards wealth, but this is not possible unless there was some outside influence (McComb, 1917b, p. 70). The example of Christ is to be copied and fulfilled by the church also in present day. McComb believes that what Christ was for Palestine then, must also the Church be for society today. This means that the church/es must take up the legacy of Christ's ministry and fulfill it in society today (McComb, 1910, p. 288). The church and its ministers do not exist for their own sake, but for the sake of the other, starting from their faith in a transcendent God. The message of the pulpit should be people oriented.

When McComb analyses the issue of poverty in the life and ministry of Jesus Christ, he comes to a quite peculiar conclusion: the issue does not present itself as important for Jesus as it does for modern society. The issue is almost inexistent. McComb also points to the reason: the eschatology of Jesus, which presents all those who suffer in this age, as inheritors of vast riches in the new kingdom. He did not come to overthrow governments and destroy political structures. He did come to reforma man, and to enable man to help fellow man. Any resort to violence and destruction does not fit the logic and moral of loving one's neighbor (McComb, 1919, p. 233). This new kingdom is a new social state, a regenerated state, which places the formerly suffering individual in complete contrast to those who kept him in that state. McComb turns to the example of Jesus and the Pharisees where he says that Caesar should get his part and God should get his part. In this new expectancy, Caesar may keep all his cut, because it amounts to nothing. The possession of earthly wealth and riches is not the reason man must live in history. If one is poor, than his share is in God, not in gold (McComb, 1910, p. 289).

The material world is put in stark contrast with the spiritual realm of God and his subsequent eternal kingdom. According to McComb Christ's message was about a conscious detachment from materialistic desires and the entrapment. The point of his message was, therefore, not material welfare. The problem itself is not the material possessions of man, but one's attachment to them. Christ is presented as the example to follow. However, following Christ is not about copying his actions, but doing the things he did, through the understanding of his reasoning. A conscious conviction is different from a bare copying action. McComb talks about Christ as having gained liberty, power, and oneness with his Father, but not only through meditation and prayer, but also by 'His own utter detachment from material things, in His perfect renunciation of all forms of self-hood' (McComb, 1910, p. 289).

This idea presents a challenge for the history of the church, because, as McComb argues, from the early church times, poverty has been constantly preached and glorified, in spite of the riches gathered by the church/es. Renunciation was presented as a sure way of gaining eternity, together with other acts, but the church had no problem in joining the political sphere. McComb underlines that the Church was not called to act as such, but in a complete submission to the freedom Christ offered through the conscious attachment to his teachings. In spite of the 'mountains of riches' and the grasping of the 'sceptre of Caesar', the Church was called to do something it never truly achieved. McComb believes Christ preached poverty in order to take man's desire for the things of sense, and turn his attention towards the things of the spirit. An immediate problem arose: poverty for the sake of poverty or poverty as an end in itself. This was not the message of Christ. The spiritual values are not meant to destroy man's joy and freedom, but to ennoble life, to lift man's value and love for oneself and for one's neighbor. The consequence of poverty for poverty's sake was that 'all life became impoverished and the healthy instincts of human nature crippled' (McComb, 1910, p. 290). Therefore, poverty is by no means what society has been seeing since the message of Christ. Instead it should be an enlightened way of life, in which genuine joy and fulfillment are the crowns of one's life. Detachment from the material things, and the conscious embrace of spiritual values, should lead to a worry free way of life, to a worldview that seeks the spiritual to the detriment of the material, and the cultivation of genuine love towards God, oneself, and one's neighbor. 
Poverty is not an end in itself, as McComb argues, because the purpose of it is to 'ennoble life, to make man larger, happier, and more effective' (McComb, 1910, p. 290). Scarcely can anyone conceptualize poverty in such terms, without thinking about the countless alcoholic and drug addicted people, whom we equate with poverty. Such poverty man cannot desire, the reaction, quite natural, is to act in such a way as to avoid it. People are involved in helping the poor, either as individuals, or as groups of volunteers, or as professional social workers. However, Christ did not preach this image of poverty, and McComb believes that the point of Christs preaching on poverty is not for man to become an alcoholic or drug addict, although this type of poverty must be addressed thoroughly. As McComb argues, the poverty Christ preached was one that was about the conscious detachment from earthly possession, or the avoidance of materialist addiction. This kind of poverty does not deny possession of goods, but it does argue freedom from the love of goods or materialistic desires. The worries associated with possession are therefore canceled, the desire to become rich is replaced with peace and a healthy reorientation towards the true values of the spirit. Self-imposed poverty guides man's principles and desires towards the 'higher regions of activity and happiness and spiritual freedom' (McComb, 1910, p. 290). This kind of poverty involves one's person, as well as the one's relations towards others. Perhaps the desires of man are connected intrinsically with what one sees around and in others' lives. However, true happiness and true human values are to be found in a healthy detachment from the materialist desires, and the new found focus on the spirit, on oneself and one's neighbor's needs.

In an unavoidable and expected contrast lies poverty as one sees it all around. McComb argues that poverty as man generally understands it 'involves no exercise of the will, no choice of the higher good, and offers no outlet into larger freedom' (McComb, 1910, pp. 290-291). Materialist poverty should have the enrichment of the soul as an almost immediate reaction. This is not the case, however, with the poor of the world, or with the poverty as an end in itself. Poverty should free men from any materialistic enslavement, in order to allow his attention to focus on spiritual values, human value, and the progression of society, and the overall humanity. As McComb presents poverty it 'degrades, debases, and enslaves man. It pollutes and destroys, but no longer emancipates' (McComb, 1910, p. 291). Misunderstood poverty and materialistic abusive love, both enslave man. The two extremes leads to no benefit, except for oneself, in the case of the materialist, and a deep dissatisfaction and depression, in the case of the poor. This kind of poverty transforms men into criminals, who, in religious terms, sin and are prone to temptations that hurts one's neighbors. The final step in the debasing situation of the poor is suicide (McComb, 1910, p. 291). Taking one's life is not the result of genuine joy or fulfilment.

The poverty recommended by Christ is different from the poverty that plagues society. The first is about ennobling and emancipating man, while the second is the result of social injustice. Inequalities between classes and the incapacity of men, governments, leaders, and organizations to solve the problem of crippling poverty only makes the desolate sight of abasing poverty even more destructive and corrosive. The common element of both kinds of poverty is the detachment from material things or riches, but the second kind of poverty brings no uplifting of the soul, no inner joy, and no pleasure in life without the possession of riches. People fear a great many things, and poverty is only one of them. However, fear is crippling, and keeps men from forming authentic moral values. They cannot be put into practice. This is why poverty cannot be addressed properly (McComb, 1915, p. 57). McComb rightly asks what the Church has done to relieve people from this kind of destructive poverty and argue in favor of the ennobling kind of poverty. McComb is well aware that the state has an active role in helping the poor, but the Church has a precise purpose in this problem. The abject poverty that McComb talks about has the destructive effect of canceling the 'moral and spiritual influences' that could help these poverty stricken to find a way out of their situation. McComb uses a strong word when talking about losing the moral and the spiritual influences, namely the word 'sterilise'. Abject poverty sterilizes both moral and spiritual influences, which means that they are completely lost and impossible to regain (McComb, 1910, p. 291).

McComb marks the difference between two types of poverty. The first is a freely accepted status, as the result of an informed and conscious philosophical or theological thought is a positive acceptance of such a situation. However, the second type of poverty leaves men without destitute. Their life is empty of any opportunities, it swirls into sadness and misunderstanding. Once these are installed in one's life, the joys of one's own home become a distant cry, and 'shuts up the sufferer in a solitude and shadows his path with fear and despair' (McComb, 1910, p. 292). The second kind of poverty is no simple matter. The church has a word and a genuine interest in solving such matters, but the financial side of the battle is clearly insufficient. The church cannot and should not eradicate poverty through material or financial means. These can be used, at best, at a local level, to relieve the poor of their immediate needs, such as food, shelter, and clothes. However, the real aid and the most effective means the church can use to eradicate poverty, or at least set an increasing trend to help the poor, is to use the pulpit or preaching in an effective way, which would ensure that the hearers - believers 
or not - change their perspective on the matter. The preacher should be able to understand how the mind works in order to properly address matters of the mind and the soul (McComb, 1909b, p. 10). If people change in the pews of most churches, the change in the matters of poverty will change as well much faster and more efficiently. The happiness of man is an important issue for society and church, but it is the system that needs to be reformed. This is necessary because it the same system that a few rich, and the many poor (Elwood et al., 1908, p. 146).

\section{The War of the Church}

The church/es do not live in an

Abstract world. Thus, the message delivered from the pulpit must reach the real life issues of the hearers. The purpose of the church, McComb believes, is 'to realise the aim of its Founder', but by doing this, the church 'must apply to the life conditions of these and such as these, the truths of the Christian doctrine' (McComb, 1910, p. 292). The Church cannot be separated from Christ. Regardless of the denomination, the figure, the message, and the ministry of Christ are all part of the essence of the church's life. Any message must address the practical side of life, the real issues faced by the congregants each day. McComb names three distinct ways in which the Church can and should implement the values of Christ in the life of modern society. The first way is to acknowledge and proclaim the sacredness of man's life for God. In other words, the Church must make sure that the message of the sermons proclaim the value of man before God. Man's value must be stated in order to make one responsible for their 'immortal destiny' (McComb, 1910, p. 292). There is a specific and well defined purpose for such a message. It refers to creating a society based on love, or the law of love. For McComb the law of love is equal to cooperation. In order for such a law to work it is imperative for greed and selfishness, to be systematically driven out from men's 'heart' (McComb, 1910, p. 293).

In this context the Church has no easy task. McComb argues that it has to 'pit its energies and wage relentless war' against poverty seen as 'malignant power' (McComb, 1910, p. 293). There are no breaks in the war against poverty and there is no postponing of efforts. If poverty is seen as a disease which ruins the souls and forces man against man, as well as takes God out of men's lives, it must be addressed as a matter of urgency. The incapacity of men to have communion and change society for the better because of poverty, presents itself as a challenge that can cripple nations, by ruining individuals. Not all advice will work on the poor, because even if some such advice seem easy to grasp and implement, the vice has a terrible force of enslaving the senses and the mind (McComb, 1917a, p. 37).

According to McComb the Church deals not only in the spiritual, but it should also be involved in 'great industrial and social problems' (McComb, 1910, p. 293). The scale to which the Church must operate is unimagined. In spite of the history of the Church's involvement in trade and politics, the new involvement in industry and the social sphere, transforms it into an institution of great importance. McComb was no stranger to what industry and social problems were in his time. The involvement of the Church meant dealing in the issues of the people working and living in the industrial environment. Being involved is not the same as identifying with a certain political or economic doctrine. McComb warns that the Church should not identify with the doctrine of Socialism, nor any of it offshoots. However, Christ's teachings do have a number of common points with actual social problems, Christ was not a socialist. The involvement of the Church should be seen in such domains as child labor, congested living quarters, and the education of the youth in physical and moral aspects (McComb, 1910, p. 293). If the Church retreats into sterile dogmatic or liturgical debates, the vast majority of the reachable will remain outside the Church. According to McComb the Church is by no means an institution that deals purely with the spiritual, but it gets down into the streets, into the cruel realities of the social realm. Some turn religion into their own most horrid fear. They worry about institutionalizing their fear, but they lack the insight for true religion, which is related to the divinity, not to man (McComb, 1909a, p. 61). It should be on constant alert in order to spot the issues that threaten or have already destroyed part of human value and the spiritual connection to God. Therefore, the Church become an important player in the realm of industrial and modern issues. The Church becomes a reformer of economics, not by speculating, but by being involved in the lives of those who make up society, the people.

A controversial issue for Christianity is to proclaim the moral structure of the Universe and the eternal judgment of God. McComb argues that these two elements are at the heart of all things. This idea has yet another practical or, rather, political aspect. McComb believes that in order for a state organized in accordance with Christian principles, it must believe that the moral structure of the Universe and the eternal judgment of God are part of its fabric. As the Church must fulfill the message 
of Christ and it must follow in His example, it must also argue in favor of society built on such principles. The State is compelled to place the moral structure at the base of all the elements that make up society, the political system, and the social structures. The principles of industry cannot be different from those of the general Christian moral principles that make up the fabric of society. The logic of McComb's social structure is that, in spite of the fact that a Christian state would need the aid of benefactors, the Church should uphold and proclaim a moral order which is based on the principle of justice (McComb, 1910, p. 294). In this society there are no individual moral structures that can work separately from the main moral structure. This does not cancel freedom of speech or freedom of will, but it does offer a fundamental principle.

\section{Extending beyond the Boundries of the Church}

The Church does not exist in a confined space, but it should reach out, beyond its members, to the world and its needs. The Church that follows the example of Christ, argues McComb, takes care of its own, but also of those who are outside the denominational or religious walls. McComb calls this kind of church the 'almoner to the poor' (McComb, 1910, p. 294). The Church is an open institution, made up of volunteers, who are, at the same time, people, human beings, prone to error, but also prone to goodness and openness in love towards their neighbor. This is why when McComb talks about the Church it can refer both to the institution - administered by the clergy, pastors, deacons; as well as to the members of these churches, the believers. Among these members there are the poor. According to McComb, they need the help of the congregation/church, but the church/congregation should not limit their help only to their own, but also to the destitute outside of the congregation, regardless of who they are and how they got destitute. The Church can be and should be, through the pulpit, a 'champion of the cause of the poor and the oppressed' (McComb, 1926, p. 13) There are three elements, in McComb's vision, that are needed in order to properly minister to the poor. First there is the need for spiritual influence. This means that the help provided through the material needs must be accompanied by a message of hope that is founded in the relationship between God and humanity. The second elements is moral uplift. This means that the message for the poor needs an element of moral guidance, which should have the result of getting one's life back on track, by giving up vices, and striving for clearness of thought, steady emotional state, and healthy body. The third element is Christian sympathy. This means that the poor who is helped must know that there is no hidden desire behind the help one receives, there is no hidden agenda, and he or she will not be the scape goat in some elaborate scheme aimed at illicit profit (McComb, 1910, p. 295). The Christians must love their fellow man. This love should be based on genuine faith in God, genuine moral construct, and genuine desire to help wherever it is necessary.

There is most important idea that McComb presents to the churches as a warning. Since charitable boards and associations came into existence, with the specific purpose of aiding the ministry and creating a professional environment for aiding and helping the needy, the church members have not been as involved in the ministry of the poor as before. Therefore, McComb argues that the churches should begin involving the members in poor-relief activities. The difference between the work done through an association and the work done by the churches is that the latter can 'console the unhappy, and the destitute, and train the soul in the spiritual values of life' (McComb, 1910, p. 295). The ministry of the church implies the active involvement of regular members, and that face to face involvement can aid the better understanding of one's capacity and the other's needs. Perhaps one the most important aspects of personal involvement is the removal of fear from the poor's heart, and replacing it with peace, fellowship, and brotherhood (McComb, 1910, p. 295). The personal involvement does not mean that the one who helps the poor will simply give without receiving anything. Instead it is a reciprocal aiding endeavor. The giver will understand better the needs of the poor, he/she will be able to develop one's humanity, care, meekness, gratitude, and one will develop genuine desire to help further.

McComb believes that in order for the Church to be or become and stay an institution of value to society, it must be in constant contact with its source of power, the spiritual realm, and its founder, Jesus Christ. However, power is not meant in a violent and oppressive manner, but as the strength to gather people, from within and without, to work together for noble causes, which would aid humanity as a whole, as well as individuals, in their ennobled human status. The Church should be the 'friend and helper of humanity', 'the defender of the weak, the poor and the oppressed', but also the 'leader in the service of man, which is also the service of God' (McComb, 1910, p. 317). If the Church manages to break the barrier of isolation and retirement into sterile theological debates, it will become an institution with a genuine human face, and a human heart. The connection between the spiritual realm and the physical realm will aid many to understand what the Church does and how it can help, together with other valuable institutions, the poor and the needy. The Church can be a paradigm shifter, and a powerful ally to anyone who desire to genuinely help the poor and the destitute. 


\section{Bibliography}

[1] Elwood, W., McComb, S., \& Coriat, I. H. (1908). Religion and Medicine. The Moral Control of Nervous Disorders. New York: Moffat, Yard and Company. Retrieved from https://archive.

org/stream/religionandmedi00mccogoog\#page/n17/mode/2up

[2] McComb, S. (1909a). The Christian Religion as a Healing Power. New York: Moffat, Yard and Company. Retrieved from https://archive. org/stream/christianreligio00worcrich\#page/60/mode/2up/search/poverty

[3] McComb, S. (1909b). The power of Self-suggestion. New York: Moffat, Yard and Company. Retrieved from https://archive. org/stream/powerofselfsugge00mccoiala\#page/10/mode/2up

[4] McComb, S. (1910a). Christianity and the Modern Mind. New York: Dodd, Mead and Company. Retrieved from https://archive. org/stream/christianitymode00mcco\#page/n11/mode/2up

[5] McComb, S. (1915). Faith the Greatest Power in the World. New York and London: Harper \& Brothers. Retrieved from https://archive. org/stream/faithgreatestpow00mccorich\#page/56/mode/2up/search/poverty

[6] McComb, S. (1917a). God's Meaning in Life. New York and London: Harper \& Brothers. Retrieved from https://archive. org/stream/godsmeaninginlif00mccorich\#page/36/mode/2up/search/poor

[7] McComb, S. (1917b). The New Life. The Secret of Happiness and Power. New York and London: Harper \& Brothers. Retrieved from https://archive.

org/stream/newlifesecretofh00mccorich\#page/70/mode/2up/search/poverty

[8] McComb, S. (1919). The Future Life in the Light of Modern Inquiry. New York: Dodd, Mead and Company. Retrieved from https://archive. org/stream/futurelifeinligh00mcco\#page/232/mode/2up/search/poor

[9] McComb, S. (1926). Preaching in Theory and Practice. New York: Oxford University Press, American Branch. Retrieved from https://archive. org/stream/MN41768ucmf_2\#page/n29/mode/2up/search/poor 